Agro-Science Journal of Tropical Agriculture, Food, Environment and Extension Volume 10 Number 2 May 2011 pp. $49-57$

ISSN1119-7455

\title{
CONCENTRATION IN THE NORTH EASTERN NIGERIA'S YAM MARKET: A GINI COEFFICIENT ANALYSIS
}

\author{
Taru ${ }^{1}$, V.B., and $\quad$ Lawal $^{2} H$. \\ ${ }^{1}$ Department of Agricultural Technology Federal Polytechnic P.M.B. 35 Mubi Adamawa \\ State Nigeria \\ ${ }^{2}$ Department of Agricultural Economics and Extension Moddibo Adama University of \\ Technology P. M. B. 2076 Yola, Adamawa State Nigeria
}

\begin{abstract}
Policy formulation has failed to take cognizance of the fact that production and marketing constitute a continuum and that the absence of development in one retards progress in the other. The study analysed the concentration of yam markets in southern part of Adamawa and Taraba states. It specifically identified the degree of product differentiation, market information dissemination and determined the concentration of yam sellers in the markets. A total of 410 respondents comprising 210 retailers and 200 wholesalers were randomly sampled using simple random sampling techniques from six purposively selected yam markets namely, Ganye, Nadu and Tola markets in Adamawa State and Wukari, Sarkin-Kudu, and Chanchanjim markets, Taraba State. Descriptive statistics, Gini coefficient and Lorenz Curve were the analytical tools used. The common features used in yam differentiation were yam varieties and size or length and market information were majorly disseminated by means of personal contact (verbal message) and telephone (GSM). The Gini coefficient of 0.56 and 0.52 were obtained for wholesaling and retailing, respectively. The concentration of sales was high with high income inequality in yam wholesaling than retailing in the area. This difference could result from the differences in their access to ownership and control of physical marketing facilities, funds availability and market behaviour and conducts. The markets therefore exhibit features of imperfect markets of oligopolistic competition. To reduce high concentration and income inequality among sellers especially in wholesale business, funds, security and physical market facilities should be provided to the yam marketers in the area.
\end{abstract}

Key word:, Lorenz Curve, Gini Coefficient Analysis, Yam, Nigeria.

\section{INTRODUCTION}

The world production of yam was estimated at 28.1 million tons in $1993.96 \%$ of this came from West Africa, the main producers being Nigeria with $71 \%$ of world production; Côte d'Ivoire $8.1 \%$; Benin $4.3 \%$ and Ghana 3.5\% In the humid tropical countries of West Africa, yams are among the most highly regarded food products and are closely integrated into the social, cultural, economic and religious aspects of life (www.fao.org/dorep/X5415E). The ritual, ceremony and superstition often surrounding yam cultivation and utilization in West Africa is a strong indication of the antiquity of use of this crop. Nigeria, the world's largest yam producer, considers it to be a "man's property" and traditional ceremonies still accompany yam production indicating the high status given to the plant. White guinea yam (Dioscorea rotundata) is the widely grown and preferred yam species. It is also one of the staple food crops grown in large scale in Taraba State and southern part of Adamawa State. Though Taraba State has been rated as the second largest Yam producing state in Nigeria with about 2,694,000 metric tons in 2006 (NBS, 2007), Adamawa State, particularly the southern part is known for its large production and marketing of yam. The crop has high nutritional and economic relevance to mankind. The tubers are eaten boiled, roasted, fried and mashed or pounded (Komolafe et al., 2001). In fact, it is acknowledged to be one of the starchy foods which provide an important energy in the tropics (Francis, 2001). It is also noted for its contribution to the growth of the Nigeria economy (Asiedu, 1999).

In view of its importance, marketing of the product becomes pertinent to meet the needs of consumers and also to increase income of the producers and the marketers in Adamawa and Taraba States. The performance and structural 
characteristics of yam markets in this area is however uncertain. This therefore calls for a research in this aspect of marketing to determine the existing market structure. Olukosi and Isitor (1990) defined market structure as those features of the organisation of a market that change nature of competition and pricing within the market. These characteristics include the number of buyers and sellers in the market, level of product differentiation, ease or barrier of exit and entry into the markets and knowledge of cost, price and market condition among the marketers in the market.

Market structure in the agricultural and food sectors has changed fundamentally and rapidly since 1950 s in developed and developing countries (in the latter countries usually with a delay of three decades or more) (McCorriston et al., 2004; Reardon and Timer, 2005). Reardon and Timer (2005) also stated that it is important to understand the market structure especially the producer-retailer relationship because it helps in the analysis of food chain. Efficient and good marketing system can only operate where there is fully utilized good market structure and conduct (Adegeye and Dittoh, 1985). Adekanye (1977) enumerated some basic decision needs to be taken on the food market structure that would lead to more effective market performance as (i) perfect competition (ii) perfect market and (iii) pricing efficiency. Another important variable in market structure analysis as stated by Okereke and Anthonio (1988) is concentration level which shows the nature of the market and pricing system.

In the opinion of Okereke and Anthonio (1988), the grain wholesaling and retailing in the eastern part of Nigeria was that of monopolistic competition. They further described the market as characterized by the presence of large number of buyers and sellers, with greater degree of concentration in the wholesale than in the retail sub-sector of the market. Ada-Okungbowa (1998) and Anuebunwa (2002) on the analyses of yam market structure in Ondo and Abia States respectively indicated high degree of inequality in income distribution among the yam sellers and that the markets were highly concentrated, exhibiting features of oligopoly. Previous studies on the marketing and pricing of staple foodstuffs in different parts of Nigeria have concluded that the marketing and pricing information transmission mechanism are inefficient, although there are many buyers and sellers in the market (Anthonio, 1968; Jones, 1969; Thodey, 1969; Dittoh, 1994; Bila and Bulama 2005; Ndaghu, et al., 2011). The paucity of physical infrastructure such as storage facilities, transportation systems, access roads, communications channels and inadequacy of economic data for planning and research are some of the factors identified as source of inefficiency. Others include a high number of intermediaries in the marketing chain, high concentration of food stuff marketing at wholesale level, as well as high and erratic prices which will further depress the level of agricultural production. Thus, oligopolistic competition is present in foodstuff marketing in Nigeria (Okoh and Akintola, 2005)

To build a profitable business, food producers seek to establish a preference to their products by differentiating those products, in some ways which are meaningful to consumers (Crawford, 1997). Methods utilized in order to differentiate a product include branding, advertising, packaging and the altering of the goods' physical characteristics such as colour and accessories. Okereke and Anthonio (1988) found out that in marketing of grain in eastern Nigeria, the distributors sell similar but not identical products and products differentiation were in terms of the size, colour and quality of grain sold. Bila and Bulama (2005); Adinya et al. (2007) on their studies of market structure of Maiduguri Cattle Market and Ofatura Goat Market showed that the products were differentiated based on the size, age, weight, colour and breeds of the animals.

According to Shephard (1997) and Yu zhau et al. (2011) producers and traders require a range of different types of marketing information. In addition to price and supplies, information is required on alternative channels, quality, means of payment and financing. Lyon (2001) reaffirmed that there is need for traders' personal network and social capital in obtaining market information. Market orientation is considered one of the modern powers of growth for the agricultural sector (Okereke and Anthonio, 1988). The role of market information is to reduce the level of risk in decision making. Through market information the sellers find out what the consumers need and wants. Crawford (1997) stated that the most important channels that marketers look out for in information are the transporters, where there is a change in market price of any product or service in the market, those closer to transporters' office get it first. Information can easily flow between sellers and buyers through personal contact (Bila and Bulama, 2005). A number of factors have been documented as influencing or stimulating trade (Anuebunwa, 2002). These include population, migration and urbanization, natural resources endowments, disposable income, ecological differences and demand level (Onyemelukwe et al., 1997). There is dearth of knowledge and information on the structure and conduct of yam marketing in north eastern Nigeria in general 
and Adamawa and Taraba States in particular.. The study extends the analysis of the market structure to the retail and wholesale. This is imperative since adequate structured markets and marketing of yam will enhance the activities of the producers and the marketers which invariably improve their standard of living.

\section{MATERIALS AND METHOD \\ Sampling Techniques and Procedure}

Multi-stage, purposive and simple random sampling techniques were adopted in selecting respondents for the study. In the first stage, out of the six states that made up the North eastern geopolitical zone, namely; Adamawa, Bauchi, Borno, Gombe, Taraba and Yobe State. Adamawa and Taraba States were purposively sampled based on their relative importance in yam production vis-à-vis marketing. The second stage was also the purposive selection of Adamawa and Taraba southern senatorial districts also based on the knowledge that production and marketing activities of yam take place in those zones more than any other zones in the states. Three local government areas each were sampled from Adamawa and Taraba states; Mayo-belwa, Ganye and Toungo from Adamawa State and Ibi, Takum and Wukari from Taraba State. One most popular yam market was purposively selected out of each of the three Local Government Areas selected. These markets were: Ganye main market in Ganye, Tola market in Mayo-belwa and Nadu market in Toungo as well as Wukari main yam market in Wukari, Sarkin-Kudu yam market from Ibi and Chanchanji yam market from Takum Local Government Areas. Unlike in Taraba state where there were strictly yam markets, in Adamawa State the markets were heterogeneous in nature as lots of other agricultural commodities are found though yam dominate the marketing activities.

The sampling frame for the selection of the respondents were collected from the heads of wholesalers and retailers marketing association. From these lists, each wholesalers and retailers were randomly selected giving a total of 410 respondents from the sampled markets in Adamawa and Taraba States. There were 200 and 210 wholesalers and retailers respectively.

\section{Analytical techniques}

Descriptive statistics, Gini Coefficient and Lorenz Curve were employed in analysing the data. Okereke and Anthonio (1988), Bila and Bulama (2005), and Ndaghu et al., 2011 used
Gini coefficient to determine the degree of market concentration of grains markets, Maiduguri Cattle Markets and vegetable markets respectively and adopted the formula thus;

$\begin{array}{lll}\text { G.C. } & = & 1-\sum \mathrm{XY} \\ \text { Where } & \\ \text { G.C. } & = & \text { Gini Coefficient } \\ \mathrm{X} & = & \begin{array}{l}\text { Percentage share of each class } \\ \text { or sellers }\end{array} \\ \mathrm{Y} & = & \begin{array}{l}\text { Cumulative percentage of their } \\ \text { sales }\end{array}\end{array}$
between zero to one. A perfect equality in concentration (low) of sellers is expected if G.C. tends towards zero, while perfect inequality in concentration (high) of sellers is expected if G.C. tends towards one. If G.C. $=1$, market is imperfect and if G.C. $=$ O, market is perfect and competitive.

Lorenz Curve was used to give a visualized nature of the sellers' concentration in the markets through a graphical representation. The graph of cumulative percentage of total sales is plotted against the cumulative percentage of the sellers.

It is used in economics to describe inequality in income or wealth (Damagaard, 2008). If all individuals are of the same size, the Lorenz Curve indicates straight diagonal line $\left(45^{\circ}\right)$, called the line of equality, if there is any inequality in size then the Lorenz Curve falls below the line of equality $\left(45^{\circ}\right)$.

\section{RESULTS AND DISCUSSION}

The study revealed that $51.22 \%$ of the respondents (wholesalers and retailers) differentiate the product by varieties and $39.51 \%$ differentiate by size/length of the product. This indicates that yam tubers in the markets were not considered the same in the eyes of sellers and buyers. This support the definition of product differentiation given by Olukosi and Isitor (1990) that product is differentiated when it looks different in the eyes of the consumers. Investigation also reveals that the common varieties of yam found in the markets were: "MUMUYE, GBONGO, OGOJA, PAPPER and PUNCH". The price attached to yam tubers depend so greatly on the varieties and size or length. This implies that knowing the common features used in differentiating the produce (yam) affects the respondents' income positively. 
Table 1: Distribution of Respondents by Product Differentiation

\begin{tabular}{lll}
\hline Ways of differentiation & No. of respondent & Percentage \\
\hline Based on yam bark colour & 18 & 4.39 \\
Based on yam bark texture & 20 & 4.88 \\
Based on yam varieties & 210 & 51.22 \\
Based on yam size/length & 162 & 39.51 \\
Total & 410 & 100.00 \\
\hline
\end{tabular}

Source: field Survey, 2008

Table 2: Distribution of Respondents by

Source of Information

\begin{tabular}{lll}
\hline Source of information & No. of respondents & Percentage \\
\hline Radio/Television & 20 & 4.88 \\
Posters / kleaflet & 2 & 0.49 \\
Transporters /drivers & 56 & 13.66 \\
Other marketers & 300 & 73.17 \\
Others & 132 & 7.80 \\
Total & 410 & 100.00 \\
\hline
\end{tabular}

Source: Field Survey, 2008

Table 3: Distribution of Respondents by Means of Communication

\begin{tabular}{lll}
\hline Means of communication & No. of respondents & Percentage \\
\hline Telephone (GSM) & 176 & 43.41 \\
Written letter & 8 & 1.95 \\
Personal contact (verbal message) & 220 & 53.66 \\
Others & 4 & 0.98 \\
Total & 410 & 100.00 \\
\hline Source: Field Survey, 2008 & &
\end{tabular}

Source: Field Survey, 2008

Table 2 shows the source of information in the markets. It reveals that $73.17 \%$ of the respondents got market information through other marketers, family members, friends, relatives, neighbours and so on. Other sources of information include transporters/drivers, radio/television and others constituting $13.66 \% \quad 4.88 \%$ and $7.80 \%$ respectively. This revelation is in consonant with that of Okereke (1988) that $74 \%$ and $77 \%$ of wholesalers and retailers respectively obtained market information informally from friends and colleagues meaning that market information are asymmetry. The implication of this asymmetric information according to Rashid (2010) and Rashid and Minot (2011) is that it brings about market segmentation, wider marketing margin and mistrust in the whole marketing system thereby begetting an inefficiency in the market. Table 3 indicates various means in which market information were passed onto other marketers. The study reveals that verbal message (personal contact) was the most common means of disseminating market information among traders. Another means commonly used was telephone (GSM) with $43.41 \%$. This agreed with findings of Bila and Bulama (2005) that information transfer among sellers and between sellers and buyers were through personal contact in Maiduguri cattle markets. Verbal message was commonly used probably because the receivers get detail market information and questions asked were properly answered. Furthermore, in using this means, message obtained are reliable. Telephone (GSM) was also used because most of the areas were covered with different communication networks. In addition, their literacy level of $85.37 \%$ could be an added advantage for using this means. 
Taru, V.B., and Lawal H.

Table 4: Computations of Gini Coefficient for Retailers by Monthly Sales in Southern Taraba State Yam Markets

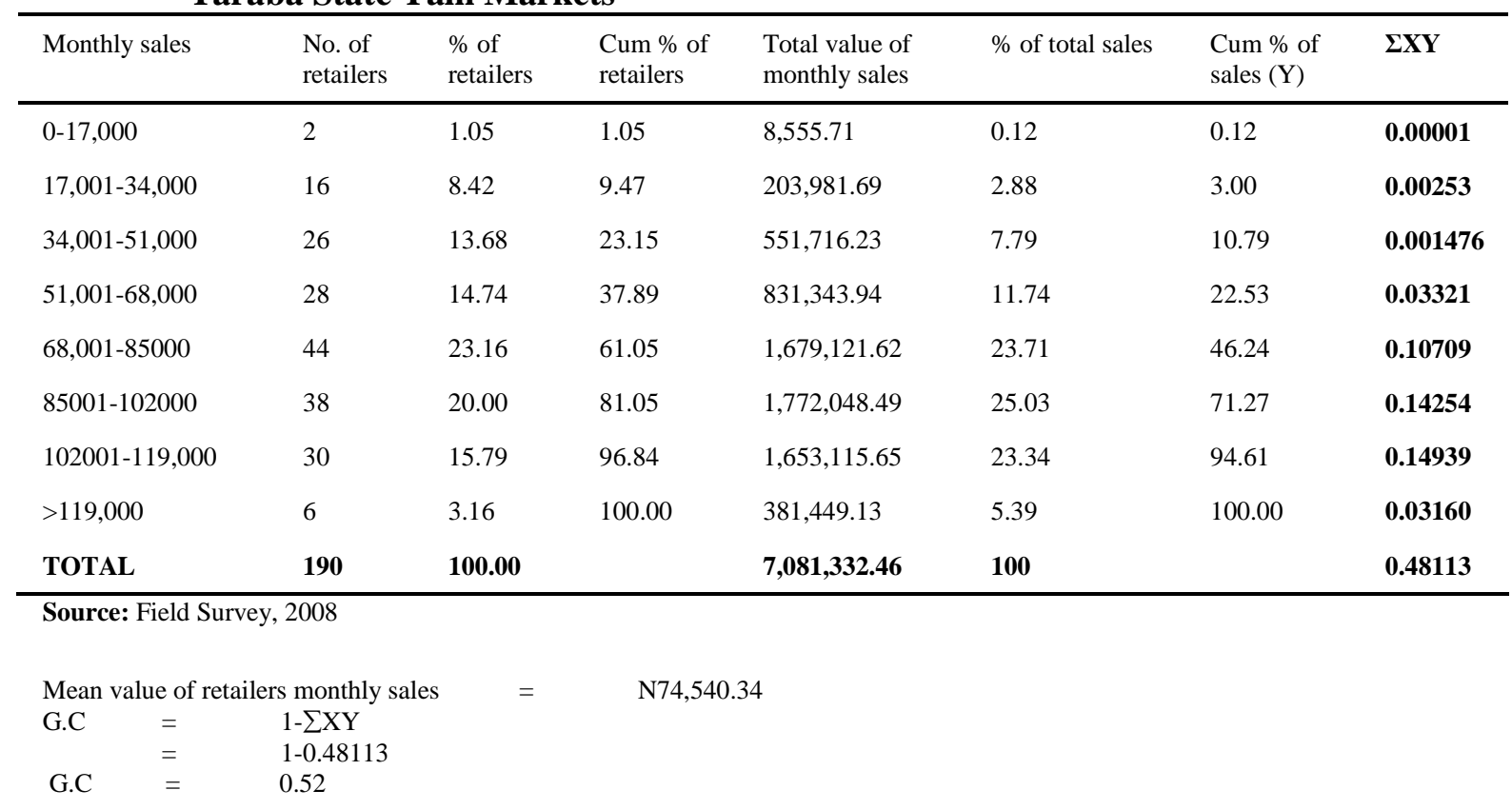

Table 5: Computations of Gini Coefficient for Wholesalers by Monthly Sales in Southern Taraba Yam Markets

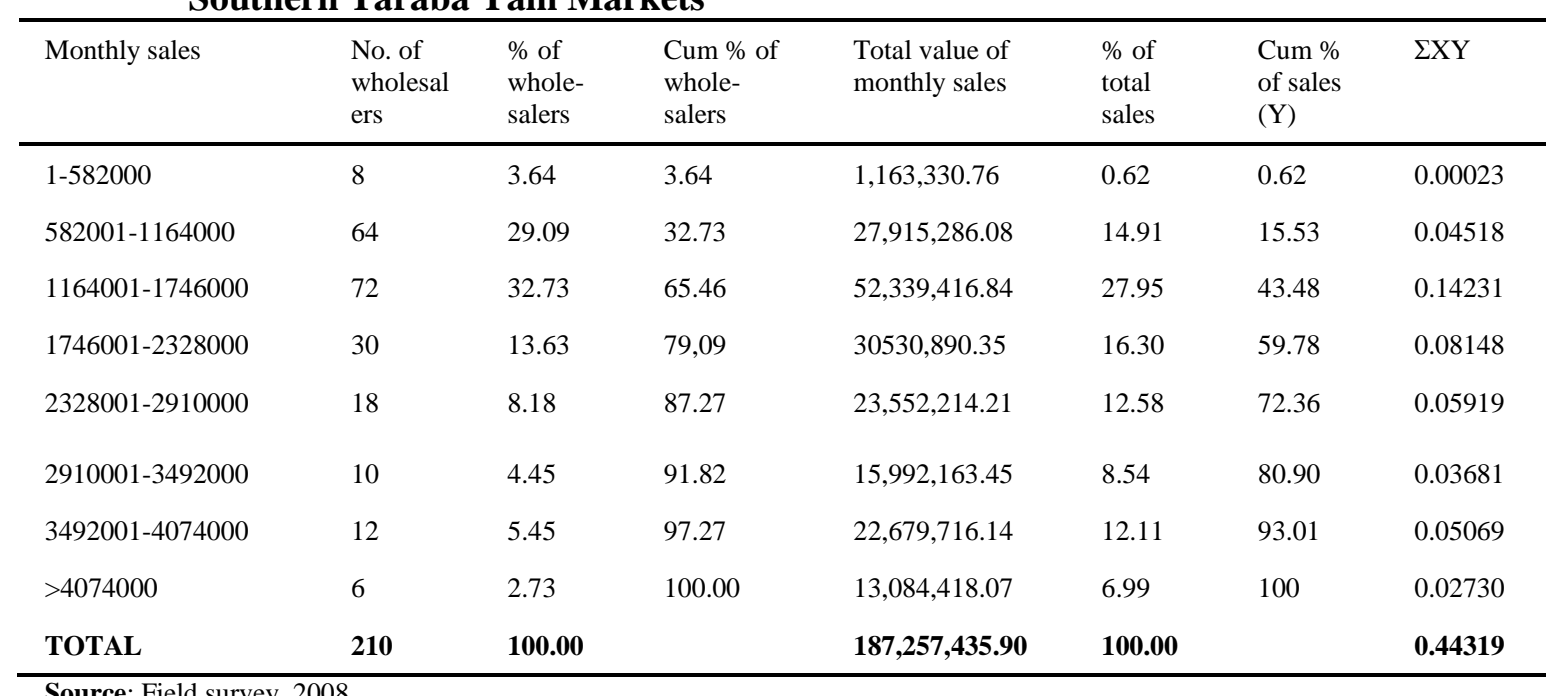

Mean value of monthly wholesaling $\quad=\quad \quad$ N170,340.00

G.C $=1-\sum X Y$

G. $1-0.44319$

G.C $\quad=0.5$ 
The result of Gini coefficient analysis shown in Tables 4 and 5 for retailing and wholesaling, respectively indicates high level of inequality in sellers' incomes and hence high level of concentration. Though, there was a relatively high income inequality and level of concentration in wholesaling (0.56) than retailing (0.52). This result agreed with the separate studies carried out by Ada-Okungbowa (1998) and Anuebunwa (2002) on yam sellers' concentration in Ondo and Abia states that there is high degree of inequality in sellers' income and that the markets were highly concentrated. The Lorenz curves shown in Figure 1 and 2 are for retailing and wholesaling, respectively. The divergence of the observed curves from the line of equal distribution (LED) gives a visual measure of concentration of both types of sellers in yam marketing in the area. The curve for retailing indicates that $52 \%$ of the retailers account for $36.93 \%$ of the total monthly sales so that the remaining ( $48 \%$ of the retailers) are responsible for $63.07 \%$ of the total monthly sales. In the case of wholesalers, it reveals that $56 \%$ of the wholesalers account for $37.2 \%$ of the total monthly sales so that the remaining (44\% of the wholesalers) are responsible for $62.8 \%$ of the total monthly sales in the area. This Gini index therefore, implies that there were income inequality in both retailing and wholesaling thus, high concentration of sellers and market power in the yam markets. These are features of imperfect market of monopolistic nature.

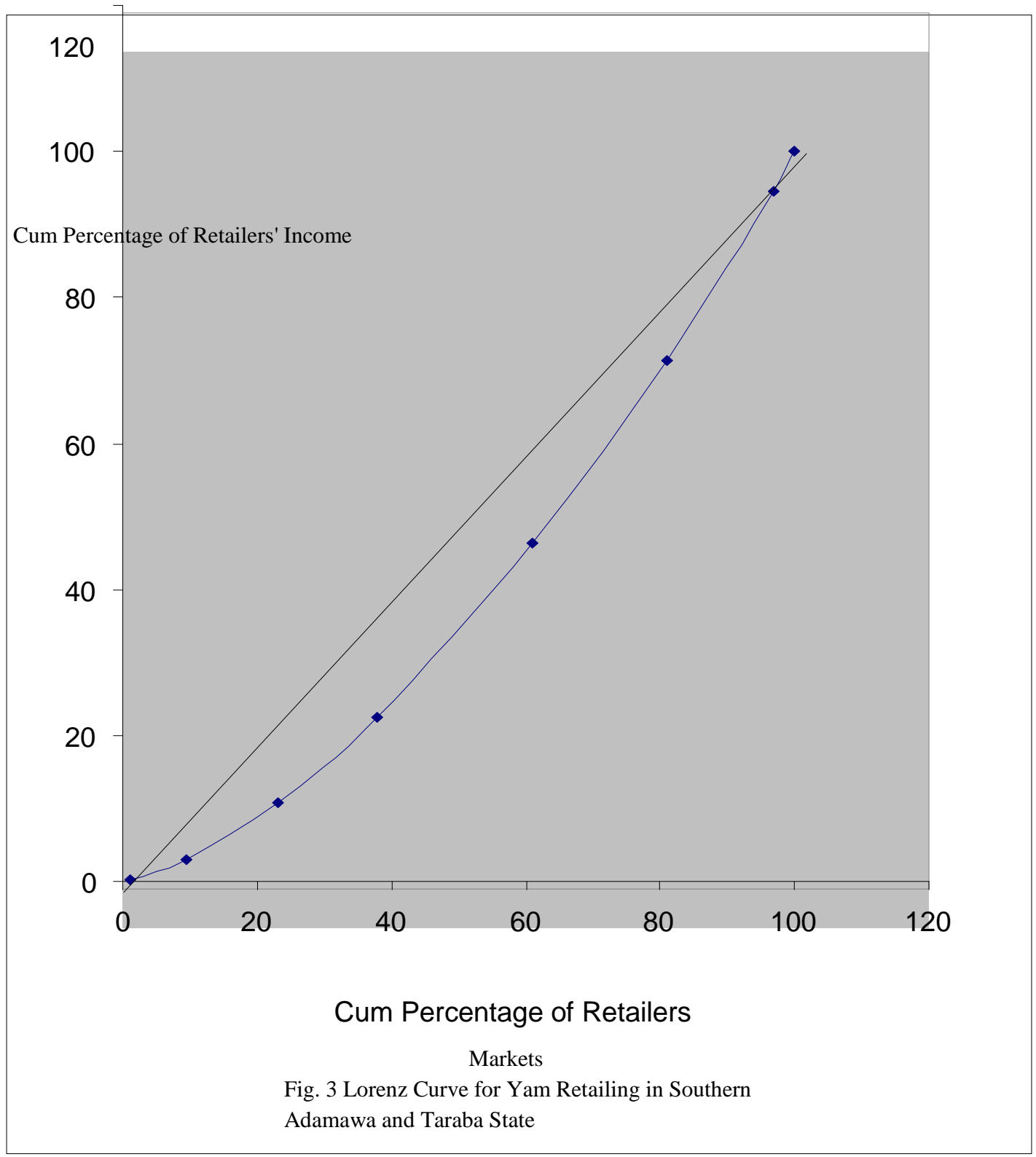




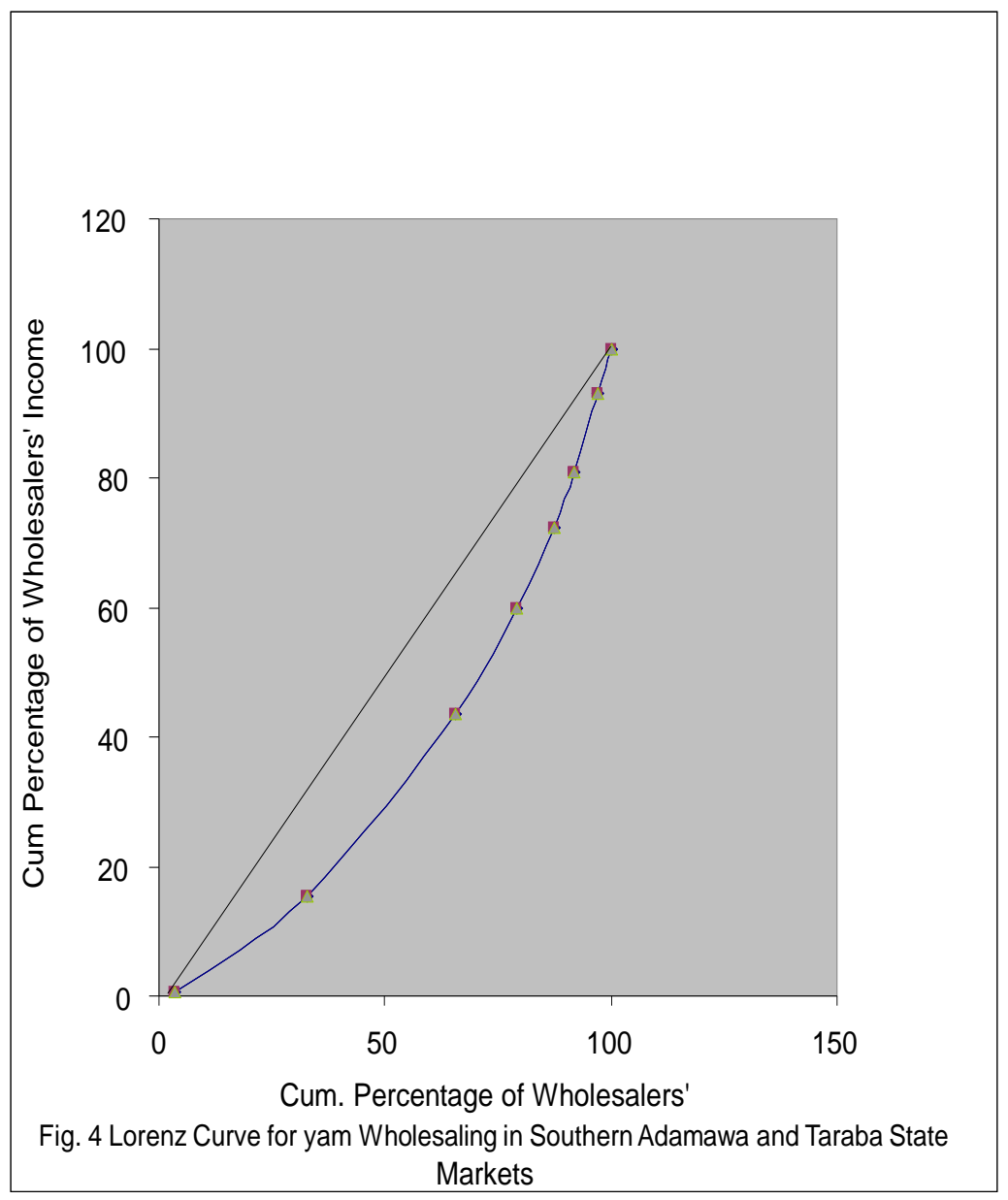

\section{CONCLUSION}

The study revealed that market information is asymmetry in nature. The yam tubers were differentiated in so many ways in the markets. Analysis unfolded that the sellers' concentration was high with high income inequality and market power exhibiting features of imperfect market of oligopolistic nature.

\section{RECOMMENDATIONS}

The exhibit of admixture of yam tubers with different sizes and varieties in the same heap for sale calls for adequate grading and standardization. This encourages collusive behaviour. Some degrees of concentration of sales exist in the yam market with greater concentration in the wholesale market. These features imply that the yam market is oligopolistic in nature and tends to expose the market towards higher profit and higher scope for middlemen exploitation. The study also calls for a good communication network to be established so as to add value to the market.

\section{REFERENCES}

Abu, G. A., Okpachu, A. S. and Ujah, J. A. (2007). Marketing of Leafy Vegetables (Telferia occidentalis' Ugu' and Amaranthus spp 'Aleifor') in Okpokwu Local Government Area of Benue State Nigeria In Proceedings of $9^{\text {th }}$ Annual National Conference NAAE. Theme: Consolidation of Growth and Development of Agricultural Sector 5th - 8th November, 2007. Bauchi Nigeria, pp. $147-153$

Ada-Okungbowa, C. I. (1998). The Market Structure, Conduct and Performance for Yam in Ondo State, Nigeria. Agrosearch, 4(1 \& 2):12-20.

Adegeye, A. J. and Dittoh, J. S. (1985). Essentials of Agricultural Economics. Impact Publishers Ibadan, $251 \mathrm{p}$. 
Adekanye, T. O. (Ed) (1977). Market Structure for Foodstuff: Problems and Prospect for Rural Development in Nigeria, Readings in Agricultural Marketing. Longman Nigeria. pp 101107

Adinya, I. B., Enya, V. E. and Kuye, O. O. (2007). Structure of Ofatura Goat Market Obubra Local Government Area of Cross-River State. Global Journal of Agricultural Sciences, 6 (1), 55-59.

Agboola, S. A. (1979). An Agricultural Atlas of Nigeria. Oxford University Press. New York. 248p

Anuebunwa, F.O. (2002). A Structural Analysis of Yam Trade Flows into Abia State of Nigeria. Nigerian Agricultural Journal, 33: 17-22.

Asiedu, J.J. (1999). Processing Tropical Crops, a Technical Approach. Macmillan Publishers, London pp. 149161

Bila, Y. and Y. Bulama (2005). Structure of Maiduguri Cattle Market, Borno State Nigeria. Global Journal of Agricultural Science, 4(2): 159 - 164.

Crawford, I.M. (1997). Agricultural and Food Marketing. Marketing and Agribusiness Text. FAO, United Nations, pp 1-33

Damagaard, C. and J. Weiner (2000). Describing inequality in plant size or fecundity. Ecology, 81: 1131-1142.

Damagaard, C. (2008). "Gini Coefficient" From Math World-A Wolfram Web Resource, created by Eric W. Wiesstein.

http//mathword.wolfram.com/gini coefficient htm/.

Dixon, P.M.,J. Weiner, T. Mitchell-olds; and R. Woodley (1988). Erratum to Boostrapping the Gini coefficient of inequality. Ecology, 69: 1307.

F.O.S. (1996). Federal Office of Statistics, Abuja, Nigeria

Food and Agriculture Organization FAO (_---). Storage and Proceessing of Roots and Tubers Crops published by agriculture and Consumer Protection, retrieved from: http//:www.fao.org/dorep/x5415E

Francis, H.B. (2001). O'Level Agricultural Science for West Africa. Macmillan Books Publishers pp. 63-65.

Komolafe, M.F., A.H. Adegbola., I.A. Are and T.I. Ashaye (2001). Agricultural Science for West African Schools and Colleges $4^{\text {th }}$ edition University Press, Ibadan, p. 90
Kotler, P. (2001). Marketing Management: Delhi Prentice Hall of India Private Ltd Millennium edition. pp 56 - 58

Lyon, F. (2001). Vegetable Market Systems in Jos Plateau, Nigeria. Rural Access Issues and Supply of Urban Food Marketing: Market access for small holder vegetable production on the Jos Plateau, Nigeria. Report for DFID.

McCorriston, S., R. Sexton and I. Sheldon (2004). Vertical Market Structure, Commodity exports and trade reform. $7^{\text {th }}$ Annual Conference on Global Economic Analysis World Bank, Washington D.C.

National Bureau for Statistics (2007). Agricultural Survey Report November, 2007. Federal Government of Nigeria. p 36

Ndaghu, A.A., V.B. Taru, and J.A. Isah (2011). Structure and Conduct of vegetable Marketing in Kwadom Yamaltu-Deba Local Government area of Gombe State, Global Journal of Agricultural Sciences, 10(1): 71-75.

NPC (2006). National Population Commission Official Gazzete, Abuja, Nigeria.

Okereke, O. (1988). Price communication and market integration: a case study for grains in Anambra and Imo states of Eastern Nigeria in T.O. Adekanye (ed) Readings in Agricultural Marketing Longman Nigeria 143-156.

Okereke, O. and Q.B.O. Anthonio (1988). The Structural Characteristics of the market for grains in Eastern Nigeria in T.O. Adekanye (ed) Readings in Agricultural Marketing Longman Nigeria. pp 116-124

Okoh, R.N. and J.O.Akintola (2005). Oligopolistic Pricing and Market Integration of cassava roots and Products in Delta and Edo States, Journal of Economics and Rural Development, 149(2): 21-44

Olukosi, J..O. and S.U. Isitor (1990). Introduction to Agricultural Marketing and Prices: Principles and Applications. Living Books series Gu. Publications, Abuja, FCT. 116p.

Onyemelukwe, J.O.C., M.O. Fulani, S.I. Ahumere (1997). Inter State trade in major foodstuffs in Nigeria, Nigeria Journal of Economics and Social Studies 19(3): 325-335.

Rashid, S. (2011). Intercommodity Price Transmission and Food Price Policies, an Analysis of Ethiopian Cereal Markets Ethiopia Strategy Programme 
11 (ESSP11) ESSP 11 Working Paper No. 22 May 2010

Rashid, S. and N. Minot (2010). Are Stable Food Markets in Africa Efficient? Spatial Price Analysis and Beyond. Paper presented at the Comesa Policy Seminar "Food Price Variability: causes, Consequences, and policy Options" on 25 - 26 January 2010 Mapotu, Mozambique under the Comesa - MSU - IFPRI African Agricultural Markets Project AAMP

Reardon, T. and P. Timmer (2005). Transformation of markets for agricultural output in developing countries since 1950: How has thinking changed? in Evenson R.E., P. Pingali and T.P.S. Chultz, Handbook of Agricultural Economics: Agricultural Development: Farmers, Farm production and Farm Markets. 3:1-20.

Shephard, A. (1997): Market Information System. AGS Bulletin FAO, Rome.pp1-5.

Yu Zhau, Yu Zhang, Xiaoming Zou, (2011). Are Chinese Soybean future efficient? A fractal analysis, African Journal of Agricultural Research, 6(16): 38973902. 